\title{
Insights into the Electron-Transfer Regime of Peroxydisulfate Activation on Carbon Nanotubes: The Role of Oxygen Functional Groups
}

Wei Ren ${ }^{\mathrm{a}, \mathrm{b}}$, Liangliang Xiong ${ }^{\mathrm{a}}$, Gang Nie ${ }^{\mathrm{a}, \mathrm{b}}$, Hui Zhang ${ }^{\mathrm{a}^{*}}$, Xiaoguang Duan ${ }^{\mathrm{b} * *}$, Shaobin Wang ${ }^{b}$

${ }^{a}$ Department of Environmental Science and Engineering, Wuhan University, Wuhan 430079, P.R. China.

b School of Chemical Engineering and Advanced Materials, The University of Adelaide, Adelaide, SA5005, Australia

* Corresponding author. E-mail: eeng@whu.edu.cn (H. Zhang).

** Corresponding author. E-mail: xiaoguang.duan@adelaide.edu.au (X. Duan).

This Supporting Information includes

37 Pages

4 Texts

25 Figures

3 Tables 


\section{List of text, table and figures}

Text S1. Electrochemical analysis tests.

Text S2. The optimization of scavengers in the PDS/CNT system.

Text S3. The fitting equations of QSARs.

Text S4. Theoretical derivation of several classical electrochemical equations.

Table S1. The physicochemical properties of three commercial CNT.

Table S2. Second-order rate constants for reactions of alcohols radicals and their partition coefficients.

Table S3. The relevant parameters for establishment of linear correlation.

Figure S1. The natural logarithm of pseudo-first order kinetics constant by the PDS/CNT system with different CNT materials. $\left([\mathrm{PDS}]_{0}=1.0 \mathrm{mM},[\mathrm{CNT}]_{0}=0.1 \mathrm{~g} / \mathrm{L}\right.$, $[\text { phenol }]_{0}=0.1 \mathrm{mM},[\mathrm{PBS}]=20 \mathrm{mM}, \mathrm{T}=25^{\circ} \mathrm{C}$ and $\left.\mathrm{pH}_{0} 7.3\right)$

Figure S2. Thermogravimetric analysis of different commercial CNT at a heating rate of $5^{\circ} \mathrm{C} / \mathrm{min}$ in nitrogen $(50 \mathrm{~mL} / \mathrm{min})$.

Figure S3. The adsorption curves of phenol with CNT-A materials (a), CNT-B materials (b) and CNT-C materials (c). $\left([\mathrm{CNT}]_{0}=0.1 \mathrm{~g} / \mathrm{L},[\text { phenol }]_{0}=0.1 \mathrm{mM},[\mathrm{PBS}]\right.$ $=20 \mathrm{mM}, \mathrm{T}=25^{\circ} \mathrm{C}$ and $\mathrm{pH}_{0} 7.3$ )

Figure S4. Correlation of $\ln k_{\mathrm{obs}}$ to PE adsorption capacity with different CNT (a), and to different pollutants adsorption capacity with CNT-A-Raw (b). ([PDS $]_{0}=1.0 \mathrm{mM}$, $[\mathrm{CNT}]_{0}=0.1 \mathrm{~g} / \mathrm{L},[\text { contaminants }]_{0}=0.1 \mathrm{mM},[\mathrm{PBS}]=20 \mathrm{mM}, \mathrm{T}=25^{\circ} \mathrm{C}$ and $\left.\mathrm{pH}_{0} 7.3\right)$ Figure S5. Removal of phenol with addition scavengers in the PDS/CNT system with CNT-A-Raw (a), CNT-A-750 (b) CNT-B-750 (c), CNT-C-750 (d) CNT-1150 (e), CNT-B-1150 (f) and CNT-C-1150 (g). ([PDS $]_{0}=1.0 \mathrm{mM},[\mathrm{CNT}]_{0}=0.1 \mathrm{~g} / \mathrm{L},[\mathrm{phenol}]_{0}$ $=0.1 \mathrm{mM},[\mathrm{MeOH}]=500 \mathrm{mM}$ or $[\mathrm{TEMP}]=10 \mathrm{mM},[\mathrm{PBS}]=20 \mathrm{mM}, \mathrm{T}=25{ }^{\circ} \mathrm{C}$ and $\mathrm{pH}_{0}$ 7.3)

Figure S6. In situ Raman spectra of PDS/CNT/PE, CNT/PE, PDS/CNT, PDS and CNT in the liquid solution.

Figure S7. The open circuit potentials of different CNT in the phosphate electrolyte. $\left([\mathrm{PBS}]=20 \mathrm{mM}, \mathrm{T}=25^{\circ} \mathrm{C}\right.$ and $\left.\mathrm{pH}_{0} 7.3\right)$. 
Figure S8. The chronopotentiometry curves on the CNT-GCE and GCE electrodes in different systems. $\left([\mathrm{PDS}]=1.0 \mathrm{mM},[\mathrm{PCs}]=0.1 \mathrm{mM},[\mathrm{PBS}]=20 \mathrm{mM}, \mathrm{T}=25^{\circ} \mathrm{C}\right.$ and $\mathrm{pH}_{0}$ 7.3)

Figure S9. Raman spectra of CNT-A materials (a), CNT-B materials (b) CNT-C materials (c), and the correlation of $\ln k_{\text {obs }}$ to $\mathrm{I}_{\mathrm{D}} / \mathrm{I}_{\mathrm{G}}$ of CNT (d).

Figure S10. Nitrogen sorption isotherms of CNT-A materials (a), CNT-B materials (b) and CNT-C materials (c).

Figure S11. Pore size distributions of CNT-A materials (a), CNT-B materials (b) and CNT-C materials (c).

Figure S12. The N1s XPS spectra on the surface of CNT-A materials (a), CNT-B materials (b) and CNT-C materials (c).

Figure S13. The O1s XPS spectra on the surface of CNT-A materials (a), CNT-B materials (b) and CNT-C materials (c).

Figure S14. Correlation of $k_{\mathrm{obs}}$ to oxygen content of CNT.

Figure S15. The Zeta potential of different CNT materials. ([PBS $]=20 \mathrm{mM}, \mathrm{T}=25^{\circ} \mathrm{C}$ and $\left.\mathrm{pH}_{0} 7.3\right)$

Figure S16. Correlation of Zeta potential of CNT to oxygen content (a), carbonyl content (b), carboxyl content (c) and hydroxyl content (d).

Figure S17. The adsorption curves of PDS by different CNT-A materials (a), CNT-B materials (b) and CNT-C materials (c); and the PDS adsorption quantity of different CNT materials $(\mathrm{d}) .\left([\mathrm{PDS}]_{0}=1.0 \mathrm{mM},[\mathrm{CNT}]_{0}=0.1 \mathrm{~g} / \mathrm{L},[\mathrm{PBS}]=20 \mathrm{mM}, \mathrm{T}=25{ }^{\circ} \mathrm{C}\right.$ and $\mathrm{pH}_{0}$ 7.3)

Figure S18. Correlation of PDS adsorption quantity of CNT to Zeta potential (a), and potential of complex to PDS adsorption quantity in the PDS/CNT system.

Figure S19. Pseudo-first-order kinetic models for phenol degradation by different applied constant potential in the anodic oxidation system. $\left([\mathrm{PE}]_{0}=0.1 \mathrm{mM},[\mathrm{PBS}]=20\right.$ $\mathrm{mM}, \mathrm{T}=25^{\circ} \mathrm{C}$ and $\mathrm{pH}_{0} 7.3$ ) 
Figure S20. Effect of varying kinds of alcohols on the degradation of phenol (a) and PDS decomposition (b); effect of different concentrations of TBA on the degradation of phenol (c) and PDS decomposition (d). ([PDS $]_{0}=1.0 \mathrm{mM},[\mathrm{CNT}]_{0}=0.1 \mathrm{~g} / \mathrm{L}$, $[\mathrm{phenol}]_{0}=0.1 \mathrm{mM},[\mathrm{PBS}]=20 \mathrm{mM}, \mathrm{T}=25^{\circ} \mathrm{C}$ and $\mathrm{pH}_{0} 7.3$ )

Figure S21. Effect of varying concentrations of $\mathrm{NaN}_{3}$ (a) and TEMP (b) on the degradation of phenol. $\left([\mathrm{PDS}]_{0}=1.0 \mathrm{mM},[\mathrm{CNT}]_{0}=0.1 \mathrm{~g} / \mathrm{L},[\mathrm{phenol}]_{0}=0.1 \mathrm{mM},[\mathrm{PBS}]\right.$ $=20 \mathrm{mM}, \mathrm{T}=25^{\circ} \mathrm{C}$ and $\mathrm{pH}_{0}$ 7.3)

Figure S22. EPR spectra obtained with addition of TEMP in the PDS/CNT system. $\left([\mathrm{PDS}]_{0}=1.0 \mathrm{mM},[\mathrm{CNT}-\mathrm{A}-\mathrm{Raw}]_{0}=0.1 \mathrm{~g} / \mathrm{L},[\mathrm{TEMP}]_{0}=10 \mathrm{mM},[\mathrm{PBS}]=20 \mathrm{mM}, \mathrm{T}\right.$ $=25^{\circ} \mathrm{C}$ and $\mathrm{pH}_{0} 7.3$ )

Figure S23. LSV curves on the glassy carbon electrode in different solutions. $(v=20$ $\mathrm{mV} / \mathrm{s},[\mathrm{PBS}]=20 \mathrm{mM}, \mathrm{T}=25^{\circ} \mathrm{C}$ and $\mathrm{pH}_{0} 7.3$ )

Figure S24. The PDS consumption by different CNT materials under the conditions with or without PE. $\left([\mathrm{PDS}]_{0}=1.0 \mathrm{mM},[\mathrm{CNT}]_{0}=0.1 \mathrm{~g} / \mathrm{L},[\mathrm{PBS}]=20 \mathrm{mM}, \mathrm{T}=25{ }^{\circ} \mathrm{C}\right.$ and $\left.\mathrm{pH}_{0} 7.3\right)$

Figure S25. Tafel curves on the glassy carbon electrode in the electrolyte and phenol solutions. $\left(\mathrm{v}=1 \mathrm{mV} / \mathrm{s},[\mathrm{PE}]_{0}=0.1 \mathrm{mM},[\mathrm{PBS}]=20 \mathrm{mM}, \mathrm{T}=25^{\circ} \mathrm{C}\right.$ and $\left.\mathrm{pH}_{0} 7.3\right)$ 
Text S1. Electrochemical analysis tests.

\section{(1) Analysis of linear sweep voltammetry (LSV)}

LSV was performed between $0.1 \mathrm{~V}$ and $1.0 \mathrm{~V}$ at a scan rate of $20 \mathrm{mV} \mathrm{s}^{-1}$ using an electrochemical workstation. The experiments were conducted in $20 \mathrm{mM}$ phosphate buffer solution (PBS) and $0.1 \mathrm{mM}$ chemical reagent (PE, $\mathrm{NaN}_{3}$ or TEMP) with a threeelectrodes-cell configuration including a working electrode $(\Phi 3 \mathrm{~mm}$ glassy carbon electrode), a counter electrode (platinum electrode), and a reference electrode (saturated silver chloride electrode), and all the potential values were normalized to the reversible hydrogen electrode (RHE) before testing.

\section{(2) Measurement of open circuit potential}

Firstly, a CNT-coated glassy carbon electrode (CNT-GCE) was prepared by dipping in the mixed isopropanol solution with $\mathrm{CNT}$ and Nafion perfluorinated resin (the binder). After drying, the CNT-GCE was dipped in $20 \mathrm{mM}$ PBS overnight maintaining a stable potential. Then the open circuit potential of CNT-GCE was monitored by chronopotentiometry analysis using a saturated silver chloride electrode as the reference electrode, and all the potential values were normalized to the reversible hydrogen electrode (RHE) before testing. PDS was added into solution to monitor the changed potential of CNT-GCE after the open circuit potential of CNT-GCE keeping stable. The potential of the complex represents the stable equilibrium potential of CNT after adding PDS.

\section{(3) Analysis of Tafel curve}

Tafel curve was obtained between $0.4 \mathrm{~V}$ and $1.0 \mathrm{~V}$ at a scan rate of $1 \mathrm{mV} \mathrm{s}^{-1} \mathrm{using}$ an electrochemical workstation. The experiments were conducted in $20 \mathrm{mM}$ phosphate buffer solution (PBS) and $0.1 \mathrm{mM} \mathrm{PE}$ with a three-electrodes-cell configuration including a working electrode ( $\Phi 3 \mathrm{~mm}$ glassy carbon electrode), a counter electrode (platinum electrode), and a reference electrode $(\mathrm{Ag} / \mathrm{AgCl}$ electrode), and all the potential values were normalized to the reversible hydrogen electrode (RHE) before testing. 
Text S2. The optimization of scavengers in the PDS/CNT system.

\section{(1) Radical quenching experiments}

Scavengers of methanol $(\mathrm{MeOH})$, ethanol (EtOH) can be used to quench both ${ }^{\circ} \mathrm{OH}$ and $\mathrm{SO}_{4}{ }^{--}$, whereas isopropanol (IPA) and tert-butyl alcohol (TBA) can be applied to selectively quench ${ }^{\circ} \mathrm{OH}$. CNT-A-Raw was employed as the target catalyst. As a result, the removal rate of $\mathrm{PE}$ exhibited no obvious change with the addition of $\mathrm{MeOH}$ and $\mathrm{EtOH}$, but the inhibitory effect became remarkable upon the introduction of TBA and IPA (Figure S20a). At the first glance, the result might seem unreasonable, because the reaction rate constant of TBA with radicals is the lowest but its inhibitory effect was the strongest among the four alcohols (Table S2). The similar phenomenon that the inhibitory effect became more obvious with the increase of TBA. ${ }^{28}$ The declined reactivity was attributed to the competitive adsorption between the reactants and TBA onto the carbon surface. Figure S20b further illustrate that TBA and IPA inhibited PDS adsorption, whereas $\mathrm{MeOH}$ and $\mathrm{EtOH}$ had little implication. The competitive adsorption could be affected by the concentration of TBA (Figure S20c and S20d).

\section{(2) Singlet oxygen quenching experiments}

$\mathrm{NaN}_{3}$ and TEMP were selected as the quenchers of ${ }^{1} \mathrm{O}_{2}$, because they would not cause direct PDS consumption. ${ }^{26}$ CNT-A-Raw was employed as the target catalyst. Intriguingly, the inhibitory effect of $\mathrm{NaN}_{3}$ for PE removal was remarkable, but TEMP seemed to be no inhibition (Figure S21). The quenching result of $\mathrm{NaN}_{3}$ was unconvincing, because there was no ${ }^{1} \mathrm{O}_{2}$ signal on electron paramagnetic resonance (EPR) spectra in this system (Figure $\mathrm{S} 22$ ). $\mathrm{NaN}_{3}$ acts not only as a quencher of ${ }^{1} \mathrm{O}_{2}$ but also an electron acceptor. ${ }^{26}$ LSV curves were further confirmed the viewpoint that the 
oxidation potential of $\mathrm{NaN}_{3}$ was lower than PE (Figure S23), suggesting that $\mathrm{NaN}_{3}$ is more vulnerable to be oxidized than PE via the nonradical electron transfer pathway. 
Text S3. The fitting equations of QSARs.

$$
\begin{array}{ll}
\ln k_{\text {obs }}=-0.45( \pm 0.05) c_{\text {oxygen }}-1.25( \pm 0.18) & \mathrm{R}^{2}=0.939 \\
\ln k_{\text {obs }}=-2.11( \pm 0.14) c_{1}-1.59( \pm 0.28) & \mathrm{R}^{2}=0.897 \\
\ln k_{\text {obs }}=-0.98( \pm 0.14) c_{2}-0.97( \pm 0.22) & \mathrm{R}^{2}=0.958 \\
\ln k_{\text {obs }}=-1.36( \pm 0.29) c_{3}-1.07( \pm 0.55) & \mathrm{R}^{2}=0.762
\end{array}
$$

where $k_{\text {obs }}$ is the pseudo-first-order kinetic rate constant, $c_{\text {oxygen }}, c_{1}, c_{2}$ and $c_{3}$ are the oxygen content, carbonyl content, carboxyl content and hydroxyl content, respectively.

$$
\begin{array}{ll}
\zeta=-4.78( \pm 0.51) c_{\text {oxygen }}-2.20( \pm 2.41) & \mathrm{R}^{2}=0.924 \\
\zeta=-14.01( \pm 2.17) c_{1}-3.42( \pm 3.31) & \mathrm{R}^{2}=0.856 \\
\zeta=-16.67( \pm 2.47) c_{2}-7.70( \pm 2.70) & \mathrm{R}^{2}=0.867 \\
\zeta=-11.49( \pm 1.89) c_{3}-2.56( \pm 3.62) & \mathrm{R}^{2}=0.840
\end{array}
$$

where $\zeta$ is Zeta potential, $c_{\text {oxygen }}, c_{1}, c_{2}$ and $c_{3}$ are the oxygen content, carbonyl content, carboxyl content and hydroxyl content, respectively. 
Text S4. Theoretical derivation of several classical electrochemical equations.

\section{(1) Three classical electrochemical equations}

Tafel equation:

$$
\eta_{\mathrm{a}}=a+b \log (j)
$$

Overpotential relationship:

$$
\eta_{\mathrm{a}}=\varphi-\varphi_{0}
$$

Electrochemical kinetic equation:

$$
j=n F k_{\mathrm{a}} c_{\mathrm{R}}
$$

where $\eta_{\mathrm{a}}$ is the overpotential of anode, $\varphi$ is the electrode potential, and $\varphi_{0}$ is the equilibrium potential, ( the minimum potential to activate the electrode reaction); $j$ is the current density; $n$ is the number of electrons participating in the anodic reaction; $F$ is the Faraday constant $\left(96500 \mathrm{C} \cdot \mathrm{mol}^{-1}\right) ; k_{\mathrm{a}}$ is the kinetic constant of anodic reaction ; $c_{\mathrm{R}}$ is the concentration of a reductant; and $a$ and $b$ are the Tafel constants.

(2) The derivation of eq. (S4)

Substituting eqs. (S10) and (S11) into eq. (S9)

$$
\begin{aligned}
& \varphi-\varphi_{0}=a+b \log \left(n F k_{\mathrm{a}} c_{\mathrm{R}}\right) \\
& \varphi=a+b \log \left(n F k_{\mathrm{a}} c_{\mathrm{R}}\right)+\varphi_{0} \\
& =a+0.43 b \ln \left(n F k_{\mathrm{a}} c_{\mathrm{R}}\right)+\varphi_{0} \\
& =a+0.43 b \ln \left(n F c_{\mathrm{R}}\right)+\varphi_{0}+0.43 b \ln \left(k_{\mathrm{a}}\right) \\
& \ln \left(k_{\mathrm{a}}\right)=2.30 \varphi / b-\ln \left(n F c_{\mathrm{R}}\right)-2.30\left(a+\varphi_{0}\right) / b \\
& =a_{\mathrm{a}}+b_{\mathrm{a}} \varphi
\end{aligned}
$$

where $a_{\mathrm{a}}=-\ln \left(n F c_{\mathrm{R}}\right)-2.30\left(a+\varphi_{0}\right) / b, b_{\mathrm{a}}=2.30 / b$. 
Table S1. The physicochemical properties of three commercial CNT.

\begin{tabular}{cccc}
\hline Test & CNT-A-Raw & CNT-B-Raw & CNT-C-Raw \\
\hline -OH content & - & $3.7 \%$ & - \\
-COOH content & - & - & $2.6 \%$ \\
Electric conductivity & $>10^{5} \mu \mathrm{S} / \mathrm{cm}$ & $>10^{5} \mu \mathrm{S} / \mathrm{cm}$ & $>10^{5} \mu \mathrm{S} / \mathrm{cm}$ \\
Inner Diameter & $3-5 \mathrm{~nm}$ & $3-5 \mathrm{~nm}$ & $3-5 \mathrm{~nm}$ \\
Length & $\sim 50 \mu \mathrm{m}$ & $\sim 50 \mu \mathrm{m}$ & $\sim 50 \mu \mathrm{m}$ \\
Outer Diameter & $8-15 \mathrm{~nm}$ & $8-15 \mathrm{~nm}$ & $8-15 \mathrm{~nm}$ \\
\hline
\end{tabular}

Note: these data were provided by Sigma-Aldrich Chemical Co. Ltd. 
Table S2. Second-order rate constants for reactions of alcohols radicals and their partition coefficients.

\begin{tabular}{|c|c|c|c|}
\hline Quencher & -OH $\left(\mathrm{M}^{-1} \mathrm{~s}^{-1}\right)$ & $\mathbf{S O}_{4}^{--}\left(\mathrm{M}^{-1} \mathrm{~S}^{-1}\right)$ & $\log P_{\text {ow }}$ \\
\hline $\mathrm{MeOH}$ & $9.7 \times 10^{8}$ & $3.2 \times 10^{6}$ & -0.77 \\
\hline $\mathrm{EtOH}$ & $(1.2-2.8) \times 10^{9}$ & $(1.6-7.7) \times 10^{7}$ & -0.31 \\
\hline IPA & $1.9 \times 10^{9}$ & $3.2 \times 10^{7}$ & 0.05 \\
\hline TBA & $(3.8-7.6) \times 10^{8}$ & $(4-9.1) \times 10^{5}$ & 0.35 \\
\hline
\end{tabular}


Table S3. The relevant parameters for establishment of linear correlation.

\begin{tabular}{ccccc}
\hline Materials & $\begin{array}{c}\text { Zeta potential } \\
\zeta / \mathrm{mV}\end{array}$ & $\begin{array}{c}\text { PDS adsorption } \\
\mathrm{Q} / \mathrm{mM} \mathrm{g}^{-1}\end{array}$ & $\begin{array}{c}\text { Potential of complex } \\
\Psi / \mathrm{V} \text { vs. SHE }\end{array}$ & $\ln k_{\text {obs }}$ \\
\hline CNT-A-Raw & $-27.40 \pm 2.96$ & $0.60 \pm 0.09$ & $0.675 \pm 0.031$ & $-3.43 \pm 0.13$ \\
CNT-A-350 & $-23.28 \pm 2.51$ & $0.69 \pm 0.13$ & $0.702 \pm 0.026$ & $-2.81 \pm 0.11$ \\
CNT-A-550 & $-18.34 \pm 0.84$ & $0.99 \pm 0.11$ & $0.725 \pm 0.023$ & $-2.47 \pm 0.13$ \\
CNT-A-750 & $-16.20 \pm 1.41$ & $1.02 \pm 0.11$ & $0.739 \pm 0.030$ & $-2.37 \pm 0.04$ \\
CNT-A-950 & $-10.23 \pm 1.81$ & $1.24 \pm 0.12$ & $0.771 \pm 0.025$ & $-1.80 \pm 0.04$ \\
CNT-A-1150 & $-7.60 \pm 1.94$ & $1.28 \pm 0.10$ & $0.791 \pm 0.009$ & $-1.71 \pm 0.04$ \\
CNT-B-Raw & $-41.40 \pm 1.27$ & $0.29 \pm 0.05$ & $0.519 \pm 0.040$ & $-5.20 \pm 0.30$ \\
CNT-B-350 & $-27.35 \pm 0.78$ & $0.41 \pm 0.08$ & $0.546 \pm 0.041$ & $-4.75 \pm 0.06$ \\
CNT-B-550 & $-19.55 \pm 2.33$ & $0.69 \pm 0.09$ & $0.680 \pm 0.018$ & $-3.40 \pm 0.12$ \\
CNT-B-750 & $-13.35 \pm 1.91$ & $1.13 \pm 0.14$ & $0.775 \pm 0.025$ & $-1.98 \pm 0.07$ \\
CNT-B-950 & $-7.92 \pm 0.96$ & $1.22 \pm 0.16$ & $0.785 \pm 0.021$ & $-1.66 \pm 0.08$ \\
CNT-B-1150 & $-4.00 \pm 0.11$ & $1.32 \pm 0.13$ & $0.815 \pm 0.032$ & $-1.62 \pm 0.11$ \\
CNT-C-Raw & $-46.25 \pm 2.90$ & $0.09 \pm 0.01$ & $0.341 \pm 0.059$ & $-7.25 \pm 0.24$ \\
CNT-C-350 & $-34.75 \pm 2.33$ & $0.42 \pm 0.08$ & $0.505 \pm 0.045$ & $-5.16 \pm 0.04$ \\
CNT-C-550 & $-22.85 \pm 3.60$ & $0.66 \pm 0.11$ & $0.589 \pm 0.035$ & $-4.12 \pm 0.09$ \\
CNT-C-750 & $-13.60 \pm 0.70$ & $0.74 \pm 0.14$ & $0.762 \pm 0.018$ & $-2.27 \pm 0.10$ \\
CNT-C-950 & $-10.98 \pm 1.11$ & $0.94 \pm 0.09$ & $0.782 \pm 0.026$ & $-2.33 \pm 0.01$ \\
CNT-C-1150 & $-8.67 \pm 1.71$ & $1.09 \pm 0.11$ & $0.797 \pm 0.015$ & $-2.26 \pm 0.08$ \\
\hline
\end{tabular}




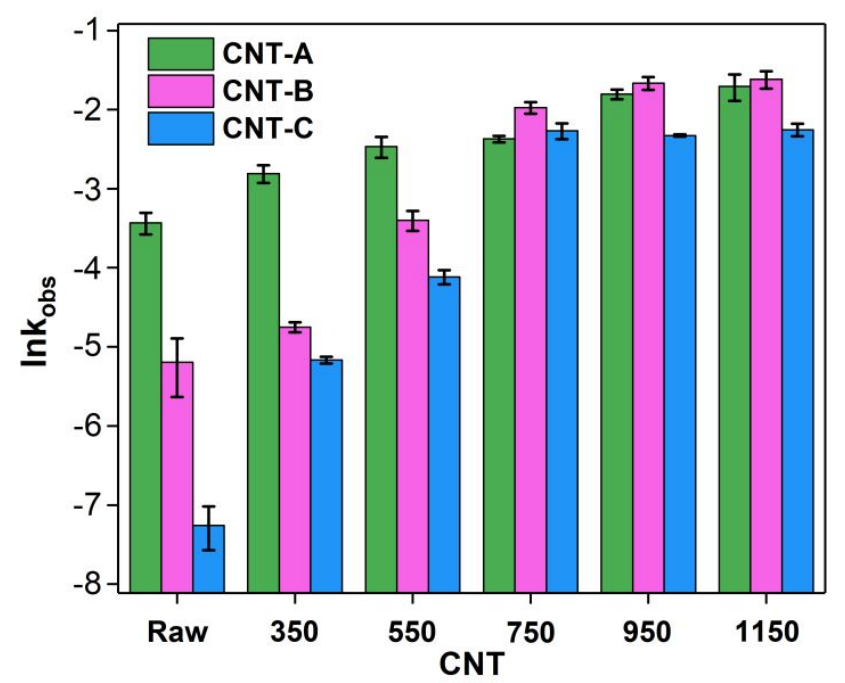

Figure S1. The natural logarithm of pseudo-first order kinetics constant by the PDS/CNT system with different CNT materials. $\left([\mathrm{PDS}]_{0}=1.0 \mathrm{mM},[\mathrm{CNT}]_{0}=0.1 \mathrm{~g} / \mathrm{L}\right.$, $[\mathrm{phenol}]_{0}=0.1 \mathrm{mM},[\mathrm{PBS}]=20 \mathrm{mM}, \mathrm{T}=25^{\circ} \mathrm{C}$ and $\left.\mathrm{pH}_{0} 7.3\right)$ 


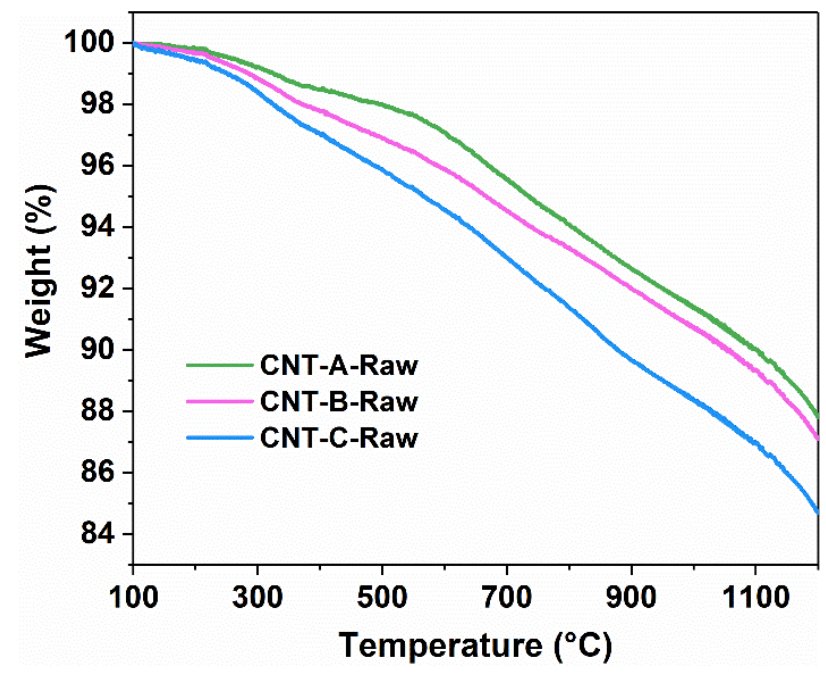

Figure S2. Thermogravimetric analysis of different commercial CNT at a heating rate of $5{ }^{\circ} \mathrm{C} / \mathrm{min}$ in nitrogen $(50 \mathrm{~mL} / \mathrm{min})$. 

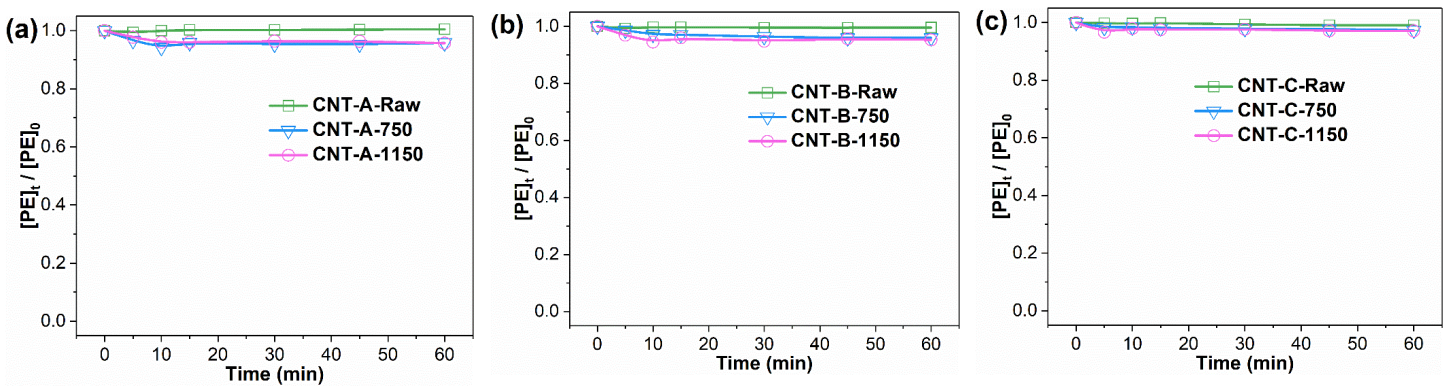

Figure S3. The adsorption curves of phenol with CNT-A materials (a), CNT-B materials (b) and CNT-C materials (c). $\left([\mathrm{CNT}]_{0}=0.1 \mathrm{~g} / \mathrm{L},[\mathrm{phenol}]_{0}=0.1 \mathrm{mM},[\mathrm{PBS}]\right.$ $=20 \mathrm{mM}, \mathrm{T}=25^{\circ} \mathrm{C}$ and $\left.\mathrm{pH}_{0} 7.3\right)$ 

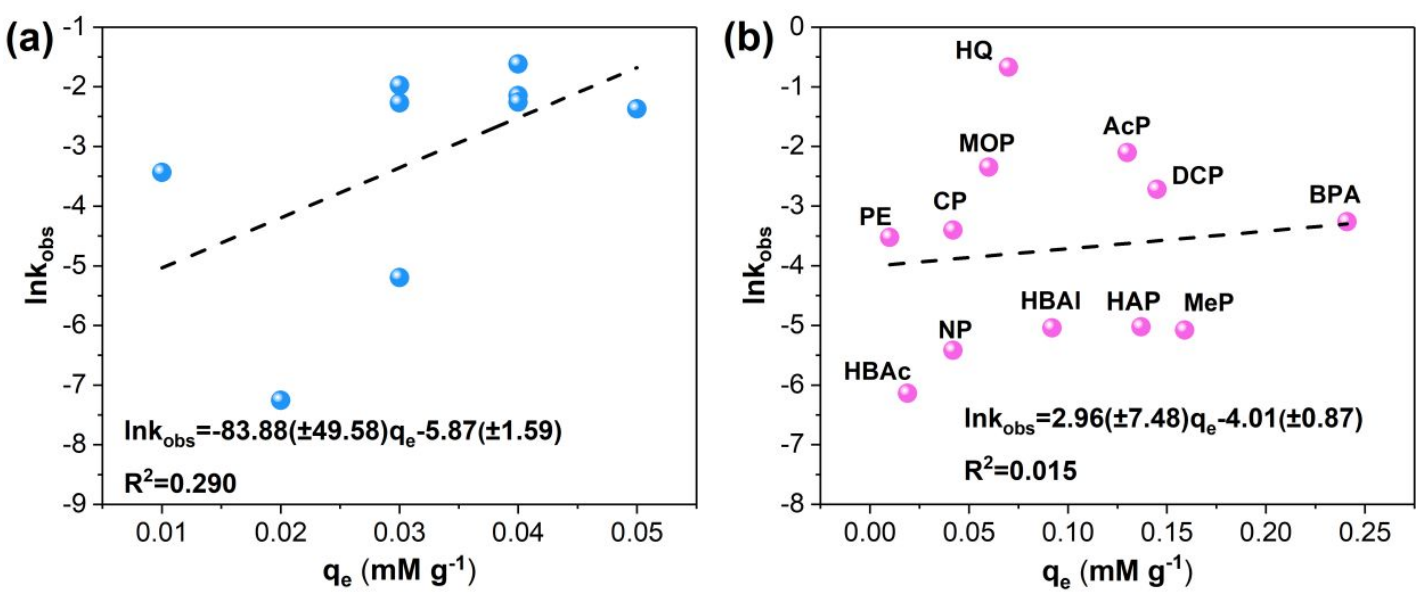

Figure S4. Correlation of $\ln k_{\mathrm{obs}}$ to PE adsorption capacity with different CNT (a), and to different pollutants adsorption capacity with CNT-A-Raw (b). ([PDS $]_{0}=1.0 \mathrm{mM}$, $[\mathrm{CNT}]_{0}=0.1 \mathrm{~g} / \mathrm{L},[\text { contaminants }]_{0}=0.1 \mathrm{mM},[\mathrm{PBS}]=20 \mathrm{mM}, \mathrm{T}=25{ }^{\circ} \mathrm{C}$ and $\left.\mathrm{pH}_{0} 7.3\right)$ 

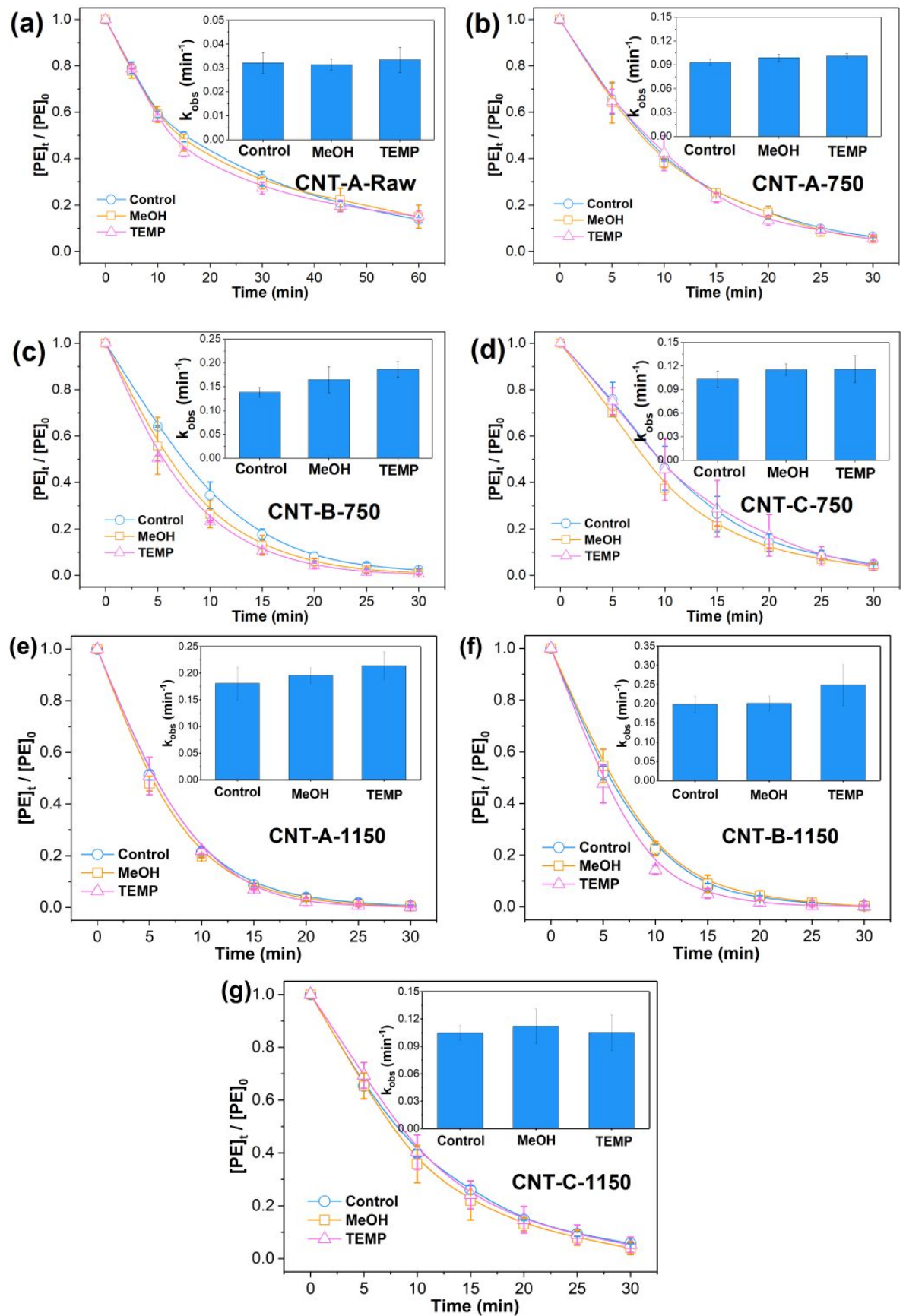

Figure S5. Removal of phenol with addition scavengers in the PDS/CNT system with CNT-A-Raw (a), CNT-A-750 (b) CNT-B-750 (c), CNT-C-750 (d) CNT-1150 (e), CNT-B-1150 (f) and CNT-C-1150 (g). ([PDS $]_{0}=1.0 \mathrm{mM},[\mathrm{CNT}]_{0}=0.1 \mathrm{~g} / \mathrm{L},[\mathrm{phenol}]_{0}$ $=0.1 \mathrm{mM},[\mathrm{MeOH}]=500 \mathrm{mM}$ or $[\mathrm{TEMP}]=10 \mathrm{mM},[\mathrm{PBS}]=20 \mathrm{mM}, \mathrm{T}=25{ }^{\circ} \mathrm{C}$ and $\mathrm{pH}_{0}$ 7.3) 


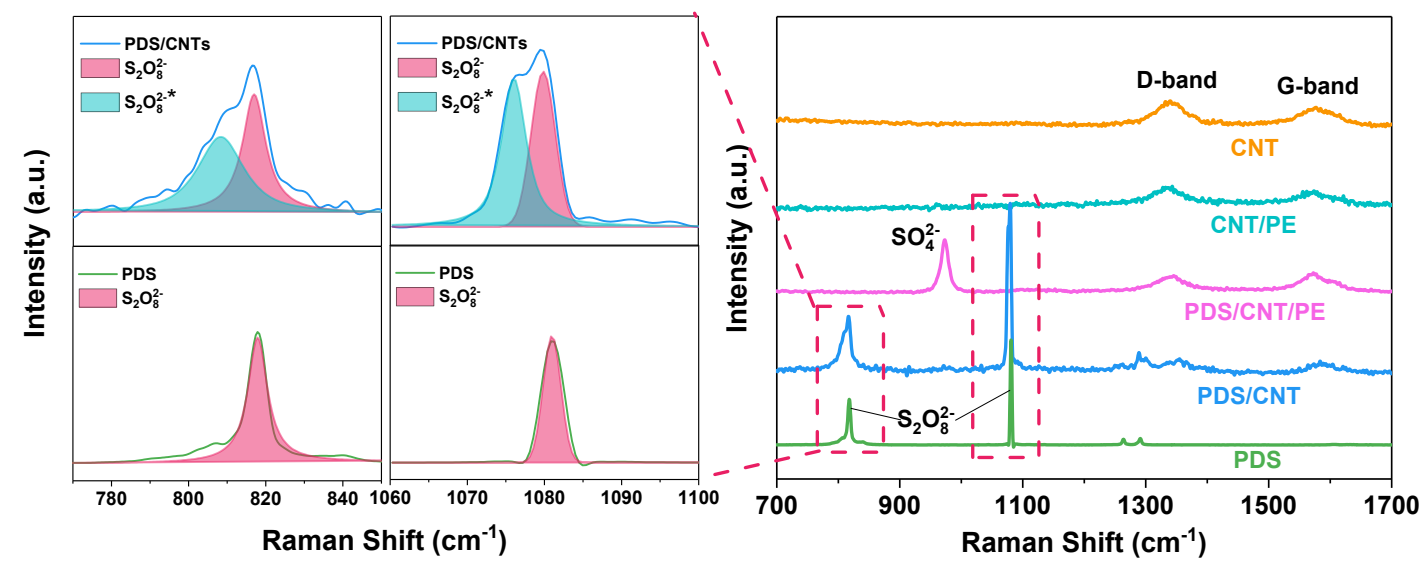

Figure S6. In situ Raman spectra of PDS/CNT/PE, CNT/PE, PDS/CNT, PDS and CNT in the liquid solution. 


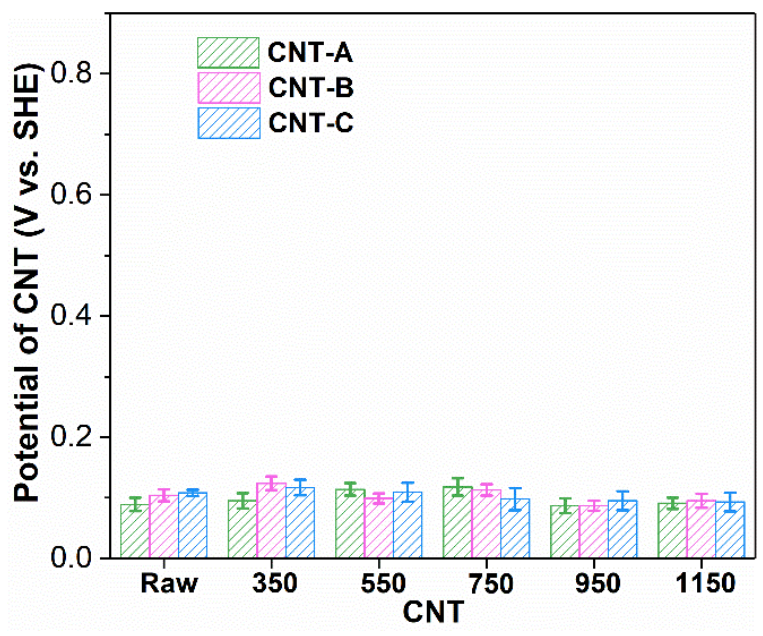

Figure S7. The open circuit potentials of different CNT in the phosphate electrolyte. $\left([\mathrm{PBS}]=20 \mathrm{mM}, \mathrm{T}=25^{\circ} \mathrm{C}\right.$ and $\left.\mathrm{pH}_{0} 7.3\right)$. 


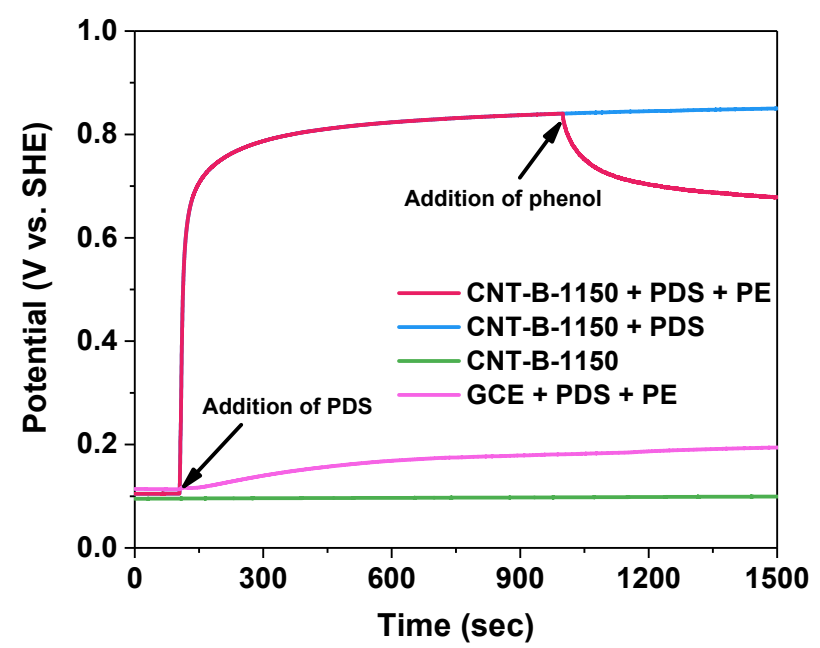

Figure S8. The chronopotentiometry curves on the CNT-GCE and GCE electrodes in different systems. $\left([\mathrm{PDS}]=1.0 \mathrm{mM},[\mathrm{PCs}]=0.1 \mathrm{mM},[\mathrm{PBS}]=20 \mathrm{mM}, \mathrm{T}=25^{\circ} \mathrm{C}\right.$ and $\mathrm{pH}_{0}$ 7.3) 

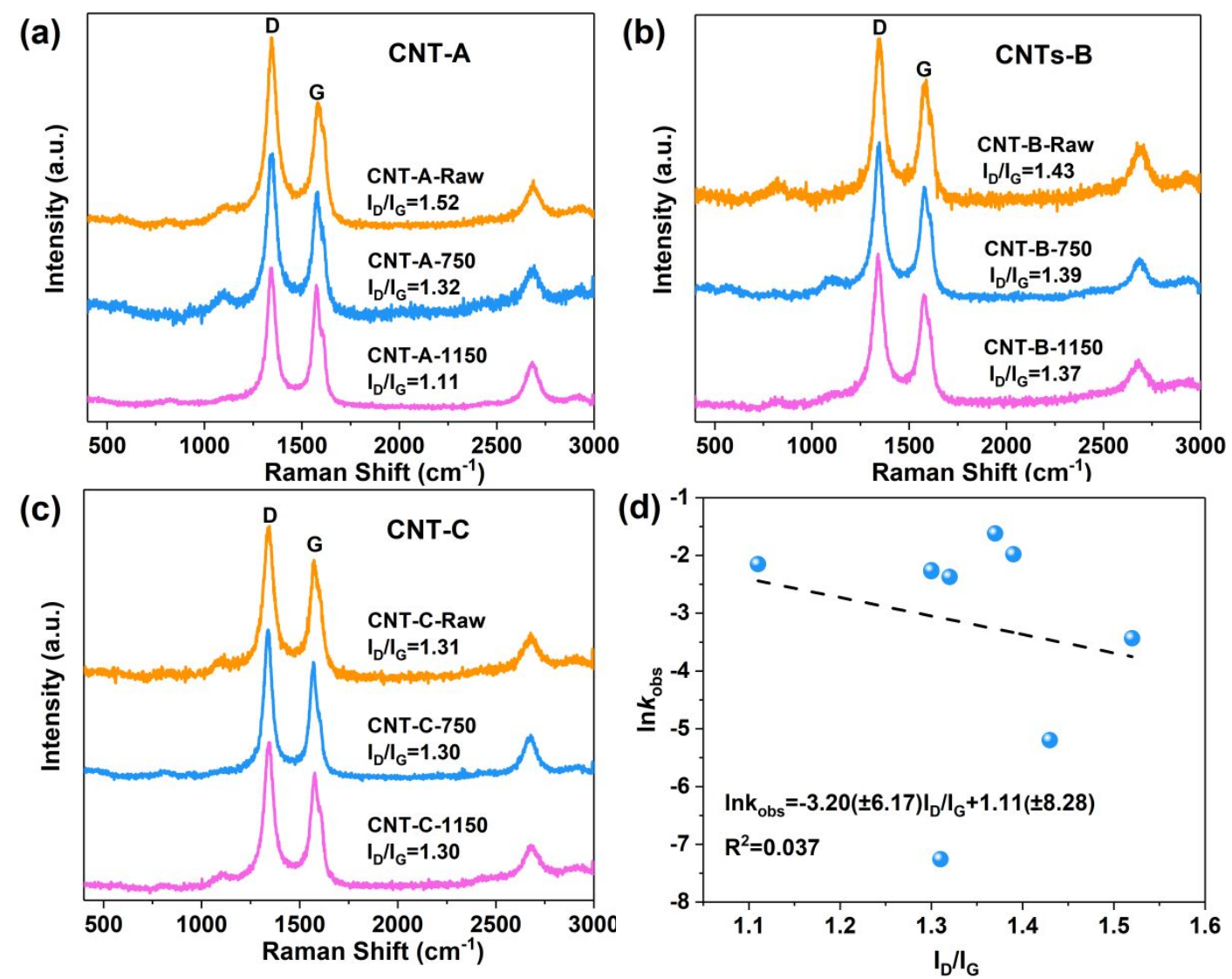

Figure S9. Raman spectra of CNT-A materials (a), CNT-B materials (b) CNT-C materials (c), and the correlation of $\ln k_{\mathrm{obs}}$ to $\mathrm{I}_{\mathrm{D}} / \mathrm{I}_{\mathrm{G}}$ of CNT (d). 

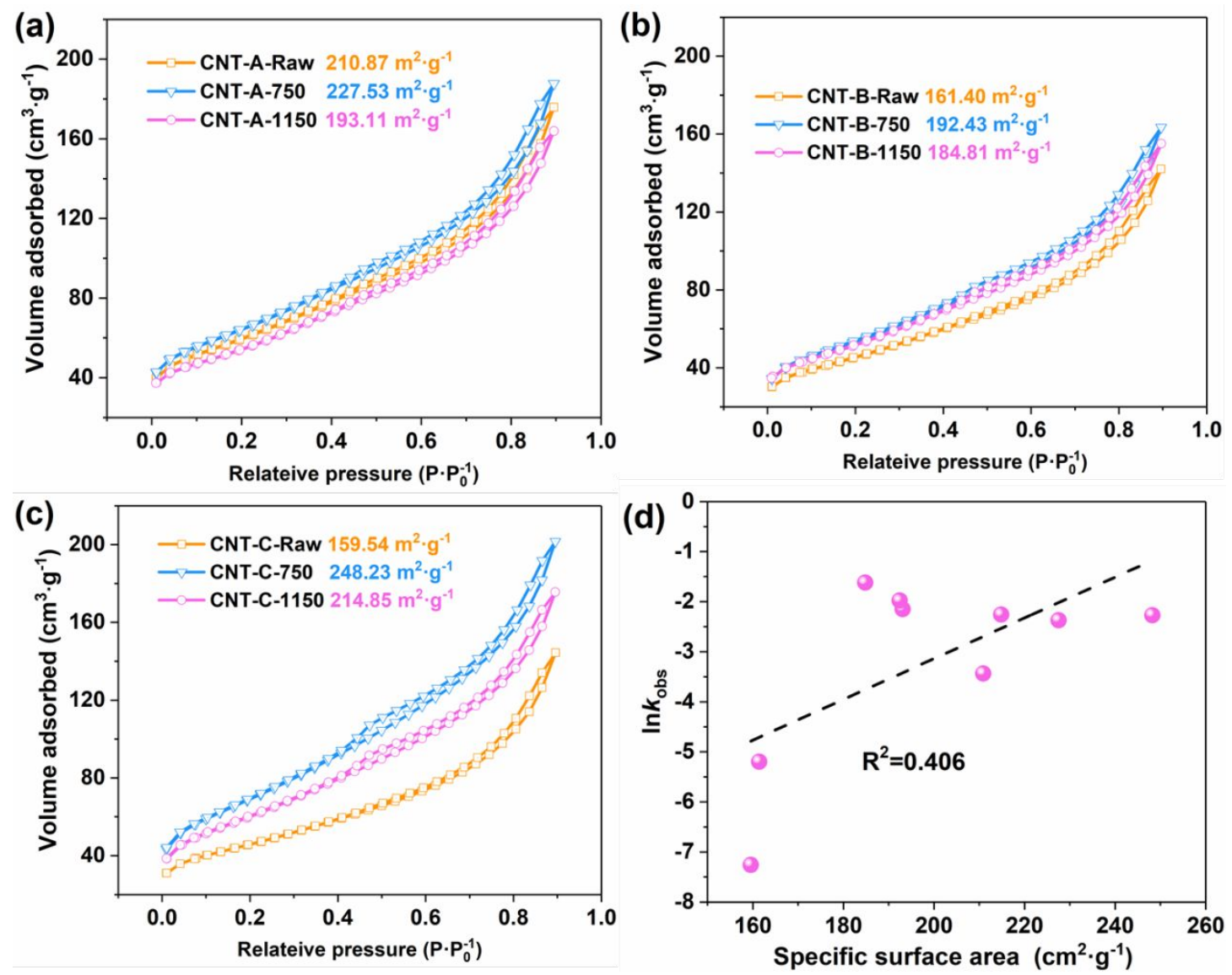

Figure S10. Nitrogen sorption isotherms of CNT-A materials (a), CNT-B materials (b) and CNT-C materials (c), and the correlation of $\ln k_{\mathrm{obs}}$ to SSA of CNT (d). 
(a)

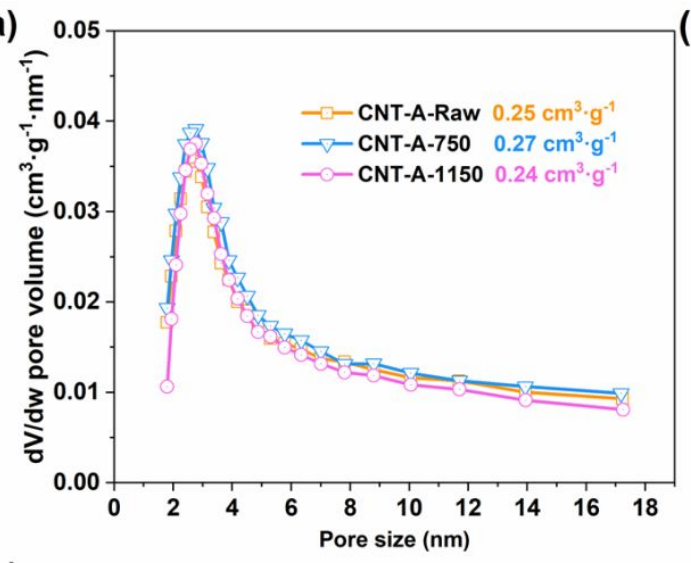

(c)

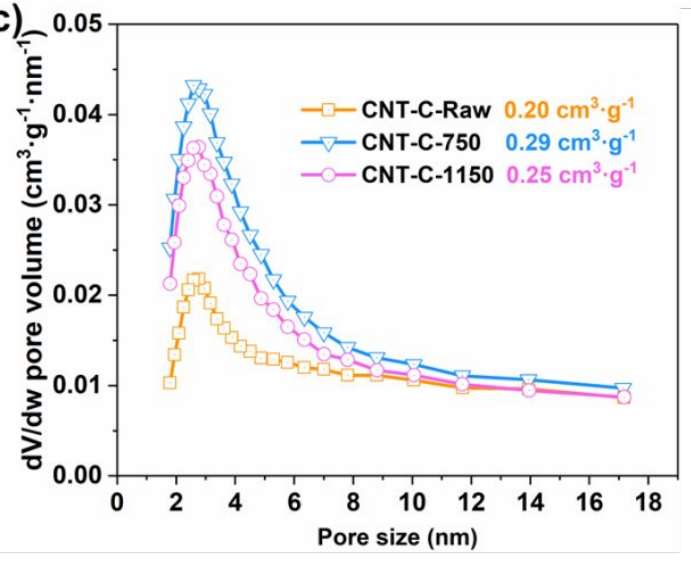

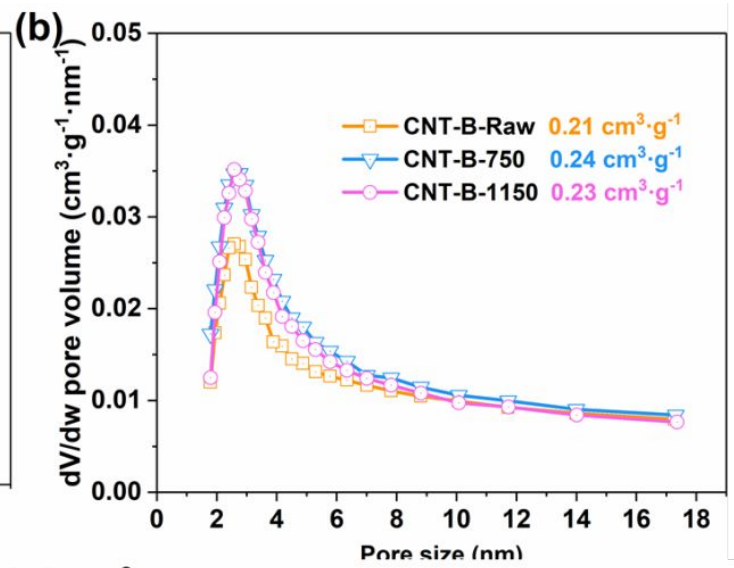

(d)

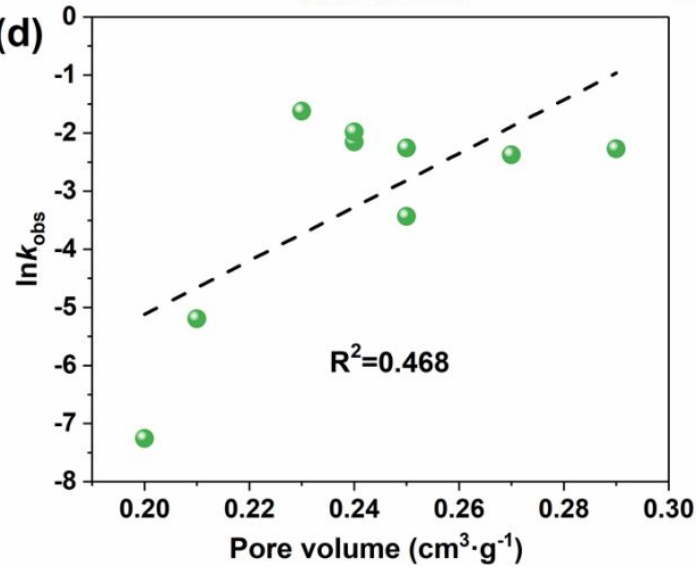

Figure S11. Pore volume distributions of CNT-A materials (a), CNT-B materials (b) and CNT-C materials (c), and the correlation of $\ln k_{\mathrm{obs}}$ to pore volume of CNT (d). 

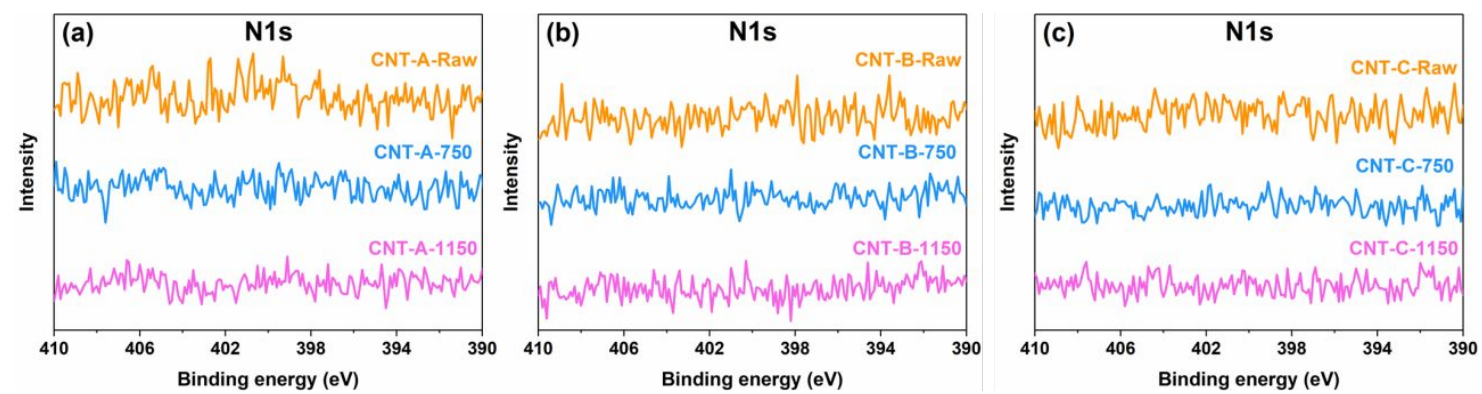

Figure S12. The N1s XPS spectra on the surface of CNT-A materials (a), CNT-B materials (b) and CNT-C materials (c). 

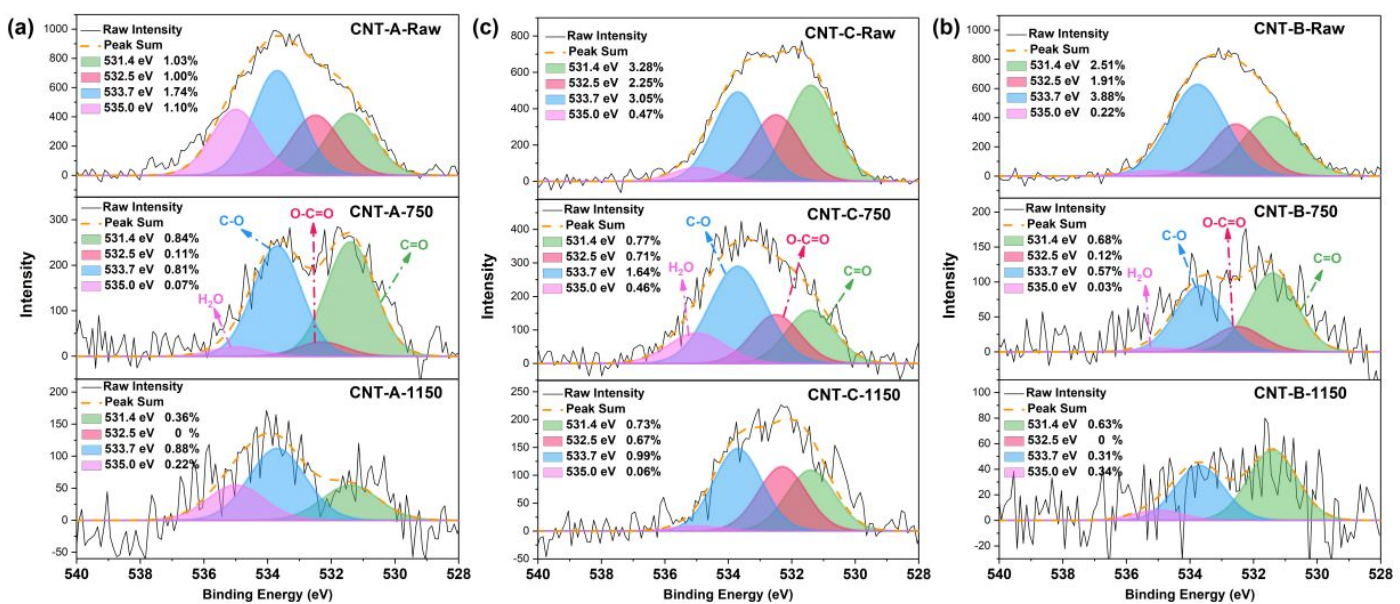

Figure S13. The O1s XPS spectra on the surface of CNT-A materials (a), CNT-B materials (b) and CNT-C materials (c). 


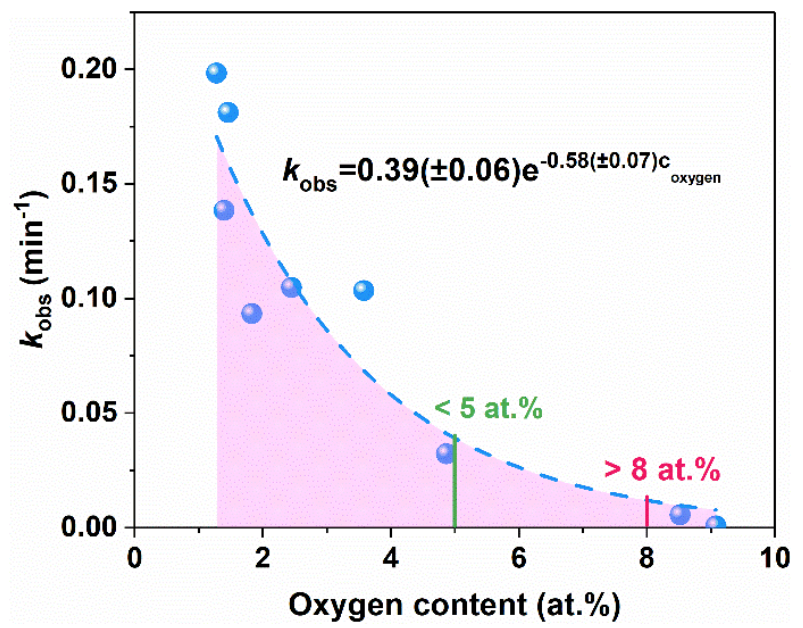

Figure S14. Correlation of $k_{\mathrm{obs}}$ to oxygen content of CNT. 


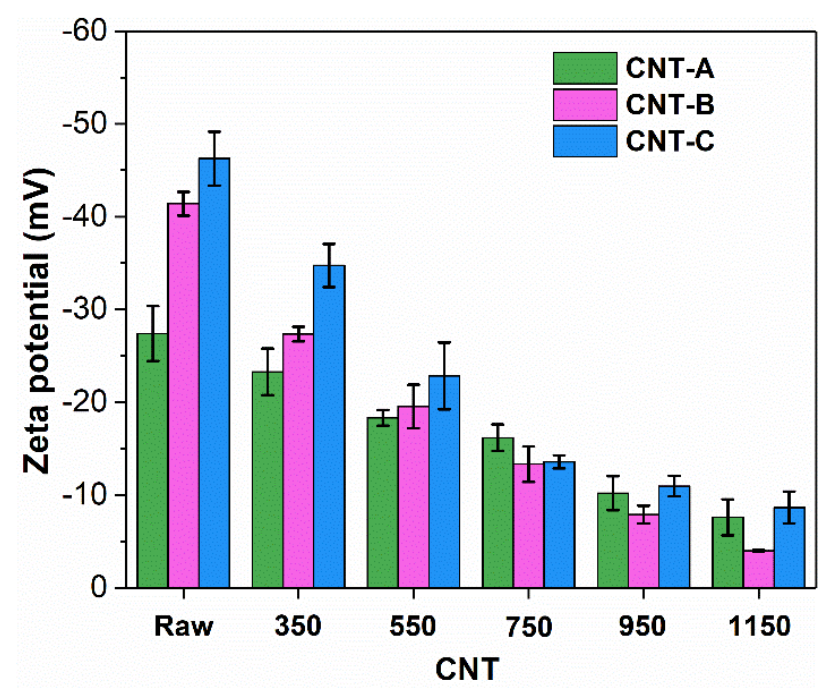

Figure S15. The Zeta potential of different CNT materials. ([PBS $]=20 \mathrm{mM}, \mathrm{T}=25^{\circ} \mathrm{C}$ and $\mathrm{pH}_{0}$ 7.3) 
(a)

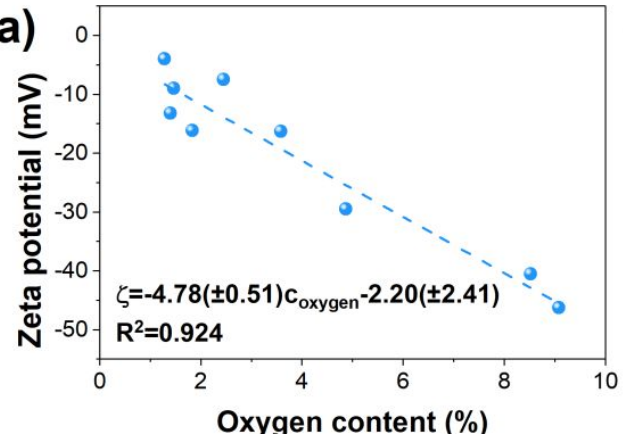

(c)

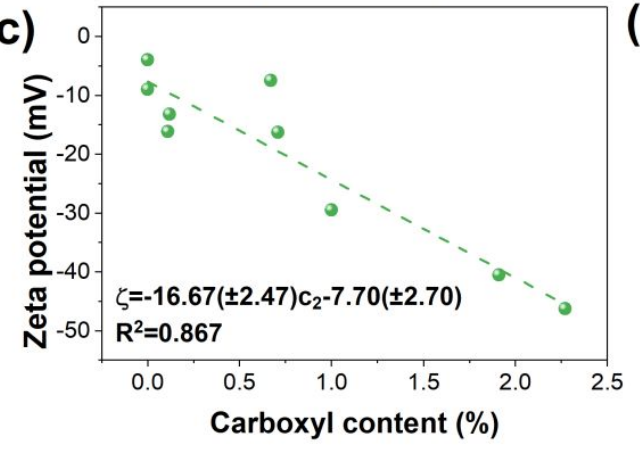

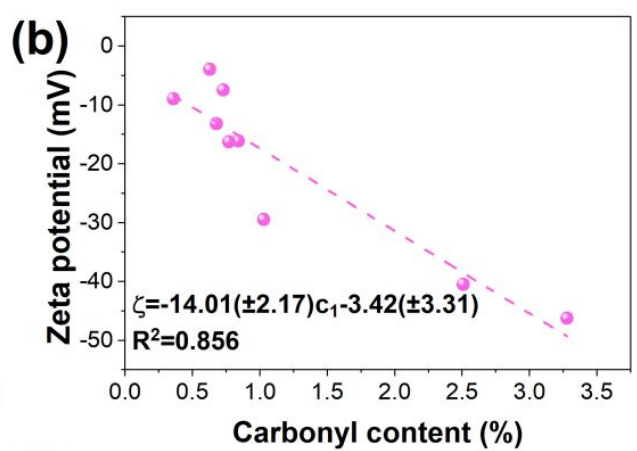

(d)

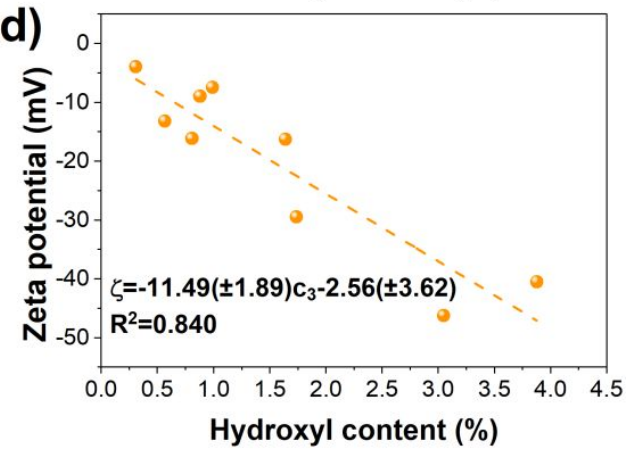

Figure S16. Correlation of Zeta potential of CNT to oxygen content (a), carbonyl content (b), carboxyl content (c) and hydroxyl content (d). 

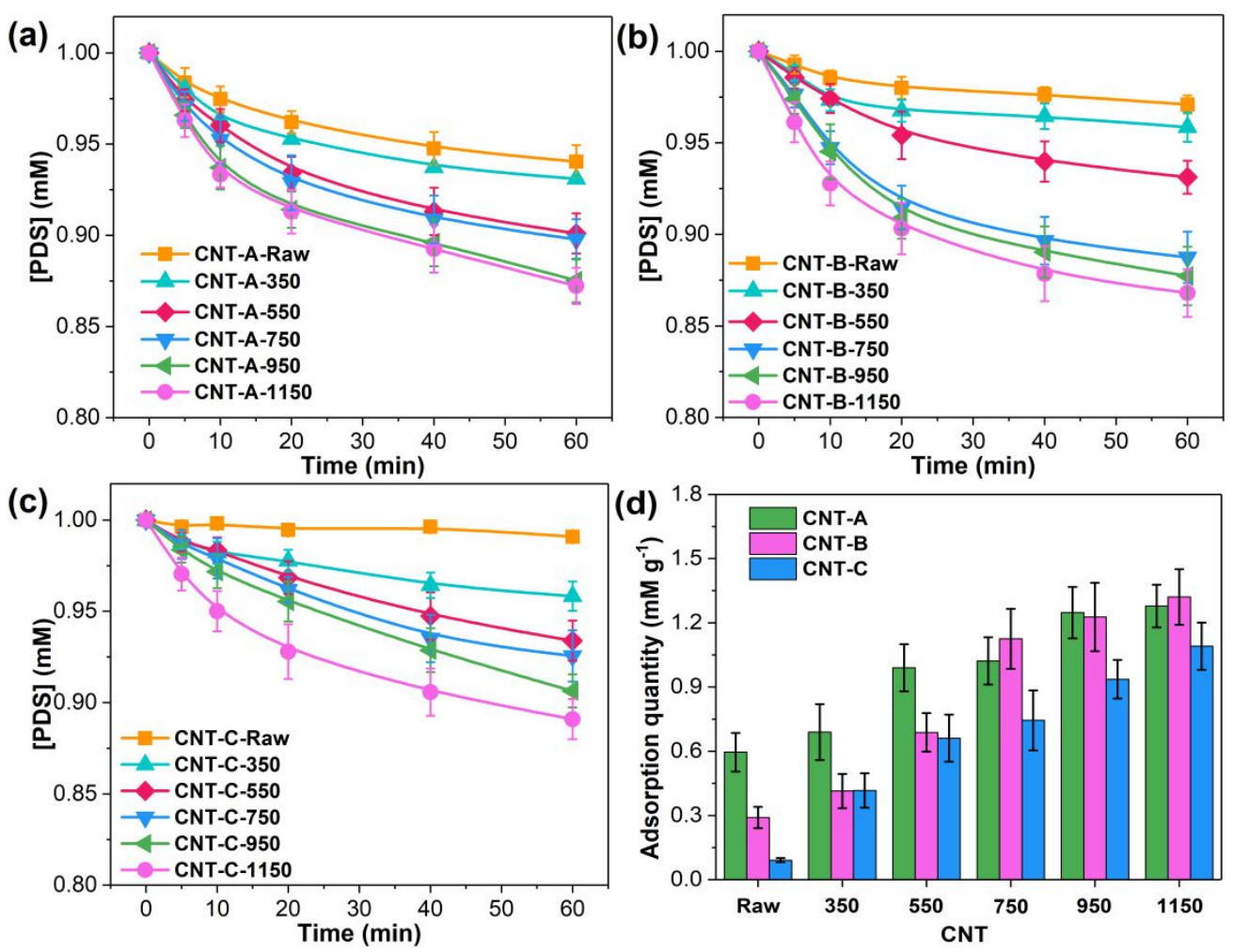

Figure S17. The adsorption curves of PDS by different CNT-A materials (a), CNT-B materials (b) and CNT-C materials (c); and the PDS adsorption quantity of different CNT materials (d). $\left([\mathrm{PDS}]_{0}=1.0 \mathrm{mM},[\mathrm{CNT}]_{0}=0.1 \mathrm{~g} / \mathrm{L},[\mathrm{PBS}]=20 \mathrm{mM}, \mathrm{T}=25{ }^{\circ} \mathrm{C}\right.$ and $\mathrm{pH}_{0}$ 7.3) 

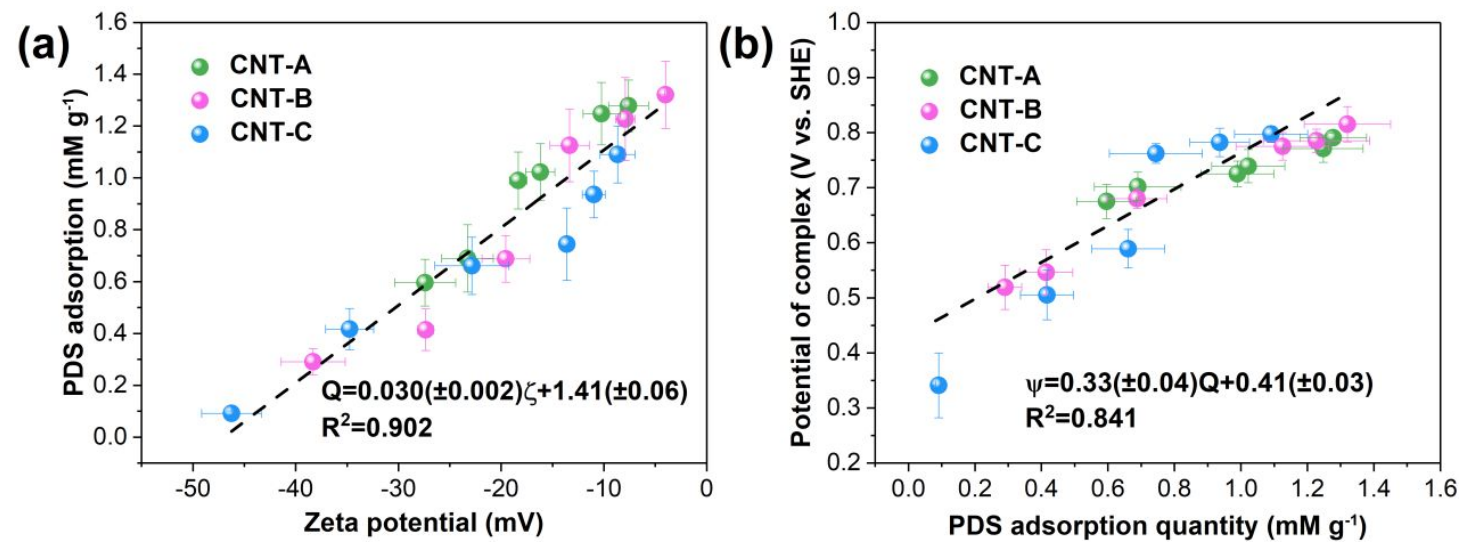

Figure S18. Correlation of PDS adsorption quantity of CNT to Zeta potential (a), and potential of complex to PDS adsorption quantity in the PDS/CNT system. 


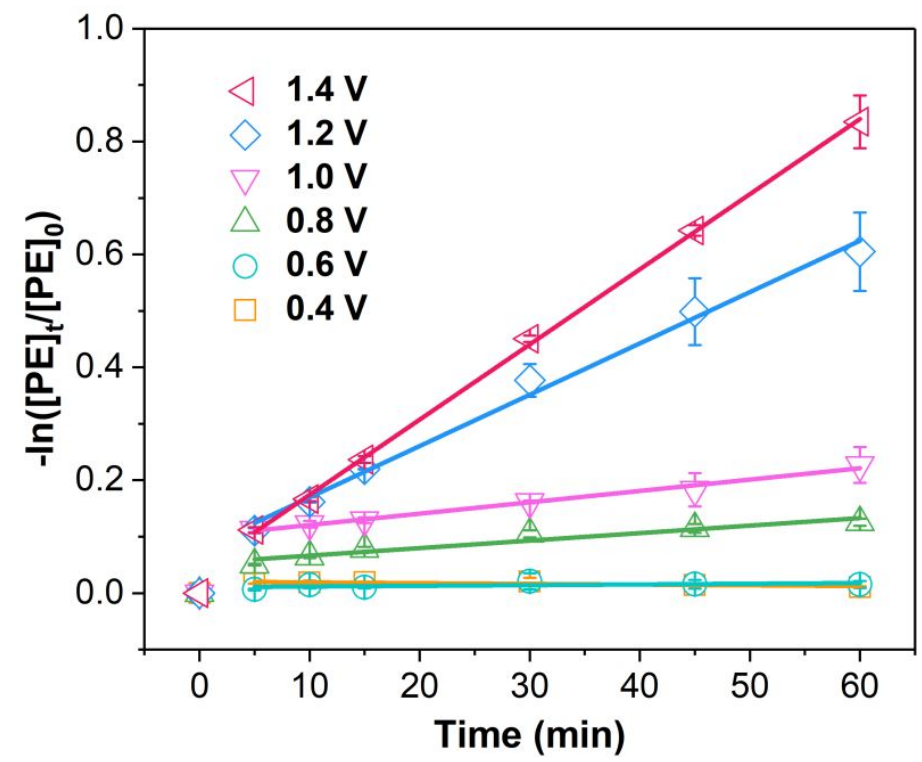

Figure S19. Pseudo-first-order kinetic models for phenol degradation by different applied constant potential in the anodic oxidation system. $\left([\mathrm{PE}]_{0}=0.1 \mathrm{mM},[\mathrm{PBS}]=20\right.$ $\mathrm{mM}, \mathrm{T}=25^{\circ} \mathrm{C}$ and $\mathrm{pH}_{0} 7.3$ ) 

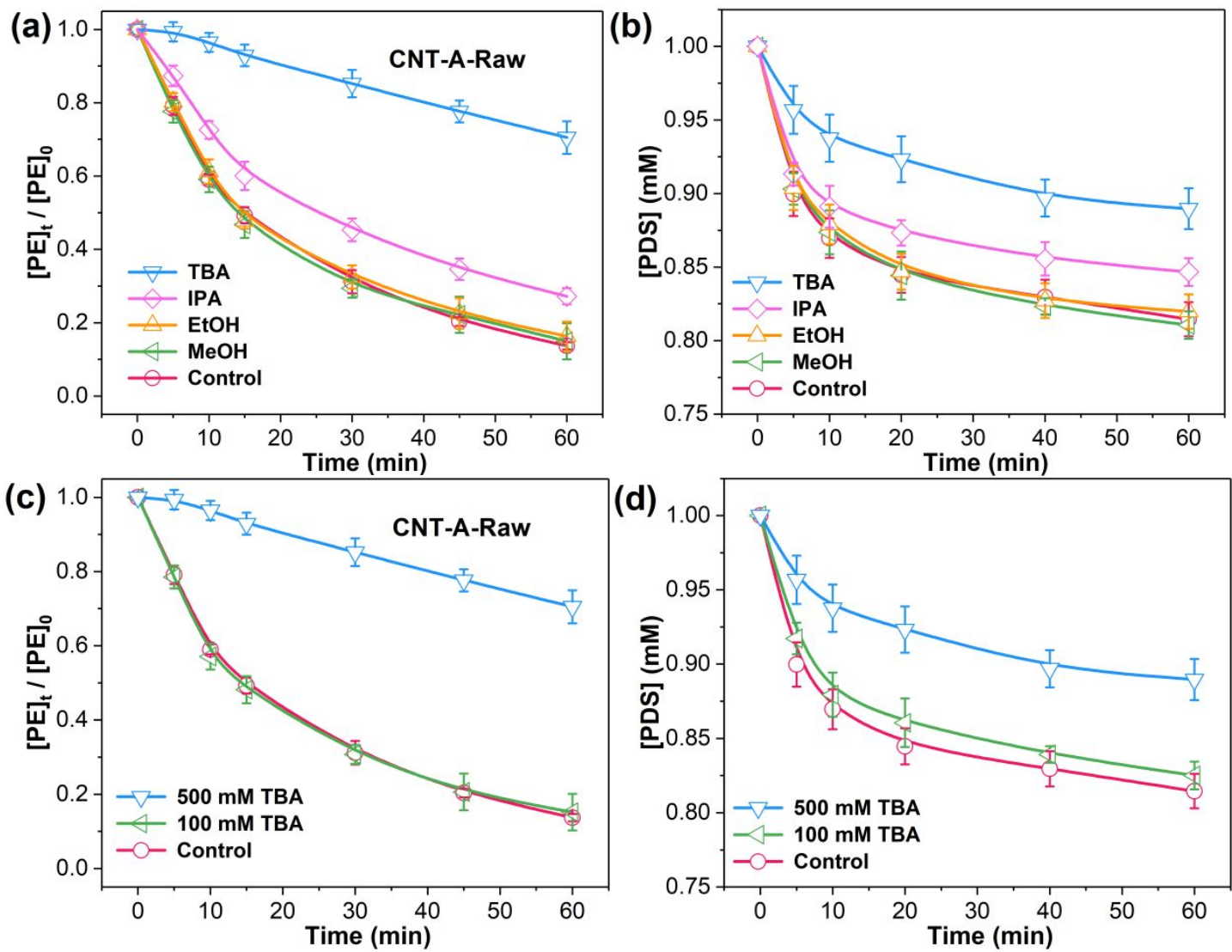

Figure S20. Effect of varying kinds of alcohols on the degradation of phenol (a) and PDS decomposition (b); effect of different concentrations of TBA on the degradation of phenol (c) and PDS decomposition (d). ([PDS $]_{0}=1.0 \mathrm{mM},[\mathrm{CNT}]_{0}=0.1 \mathrm{~g} / \mathrm{L}$, $[\mathrm{phenol}]_{0}=0.1 \mathrm{mM},[\mathrm{PBS}]=20 \mathrm{mM}, \mathrm{T}=25^{\circ} \mathrm{C}$ and $\mathrm{pH}_{0} 7.3$ ) 

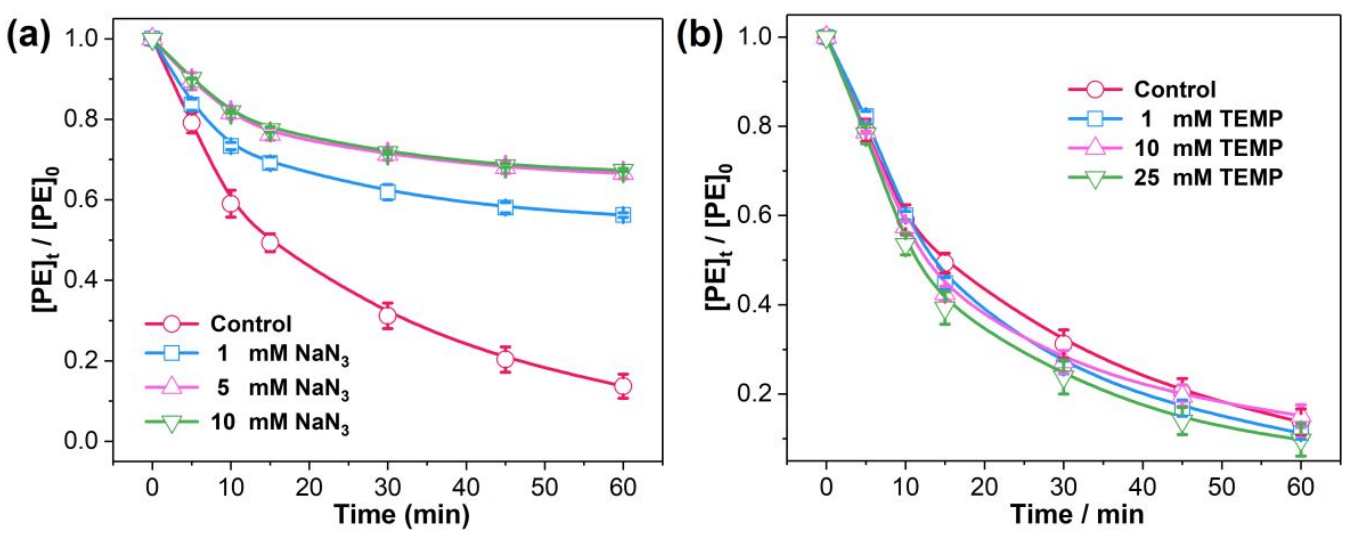

Figure S21. Effect of varying concentrations of $\mathrm{NaN}_{3}$ (a) and TEMP (b) on the degradation of phenol. $\left([\mathrm{PDS}]_{0}=1.0 \mathrm{mM},[\mathrm{CNT}]_{0}=0.1 \mathrm{~g} / \mathrm{L},[\mathrm{phenol}]_{0}=0.1 \mathrm{mM},[\mathrm{PBS}]\right.$ $=20 \mathrm{mM}, \mathrm{T}=25^{\circ} \mathrm{C}$ and $\mathrm{pH}_{0} 7.3$ ) 


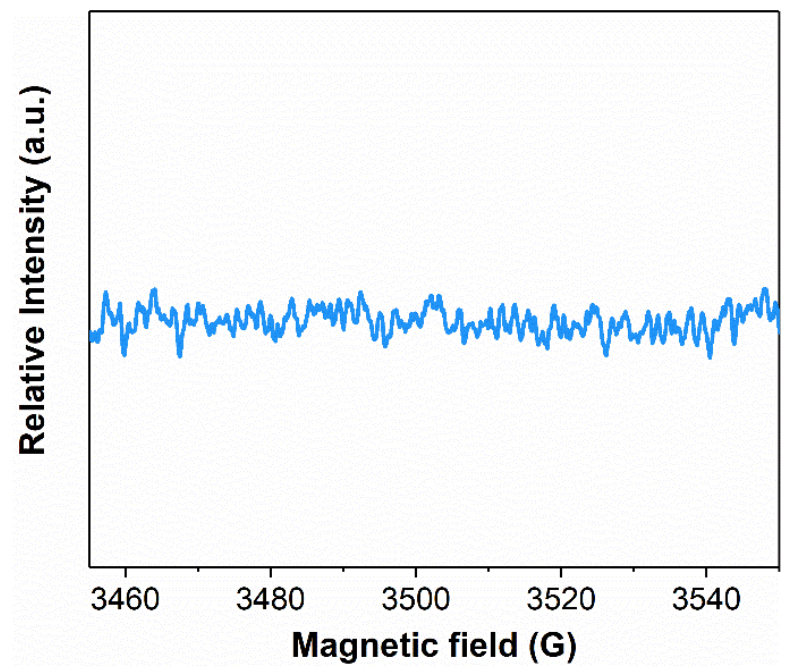

Figure S22. EPR spectra obtained with addition of TEMP in the PDS/CNT system. $\left([\mathrm{PDS}]_{0}=1.0 \mathrm{mM},[\mathrm{CNT}-\mathrm{A}-\mathrm{Raw}]_{0}=0.1 \mathrm{~g} / \mathrm{L},[\mathrm{TEMP}]_{0}=10 \mathrm{mM},[\mathrm{PBS}]=20 \mathrm{mM}, \mathrm{T}\right.$ $=25^{\circ} \mathrm{C}$ and $\mathrm{pH}_{0} 7.3$ ) 


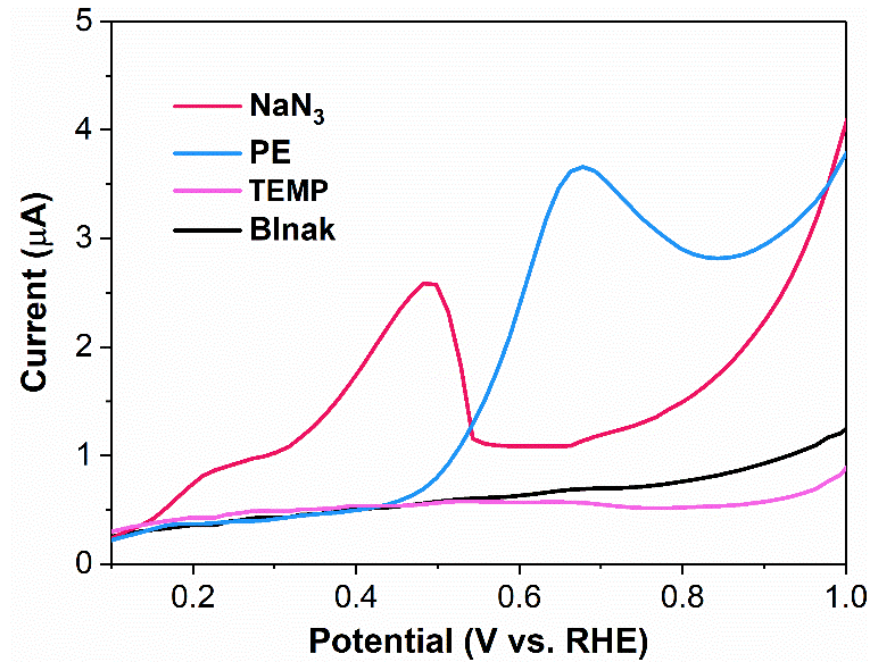

Figure S23. LSV curves on the glassy carbon electrode in different solutions. ( $v=20$ $\mathrm{mV} / \mathrm{s},[\mathrm{PBS}]=20 \mathrm{mM}, \mathrm{T}=25^{\circ} \mathrm{C}$ and $\mathrm{pH}_{0} 7.3$ ) 

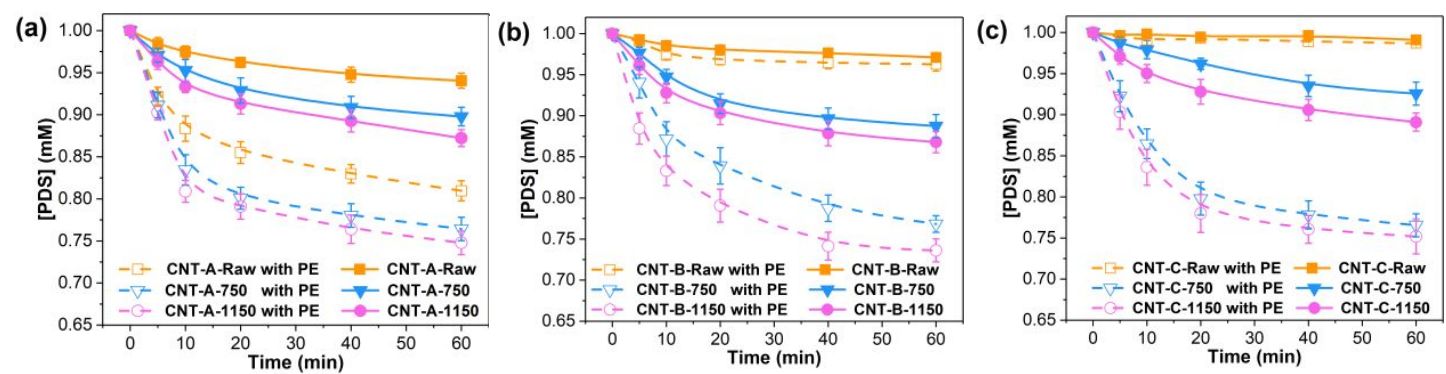

Figure S24. The PDS consumption by different CNT materials under the conditions with or without PE. $\left([\mathrm{PDS}]_{0}=1.0 \mathrm{mM},[\mathrm{CNT}]_{0}=0.1 \mathrm{~g} / \mathrm{L},[\mathrm{PBS}]=20 \mathrm{mM}, \mathrm{T}=25^{\circ} \mathrm{C}\right.$ and $\mathrm{pH}_{0}$ 7.3) 


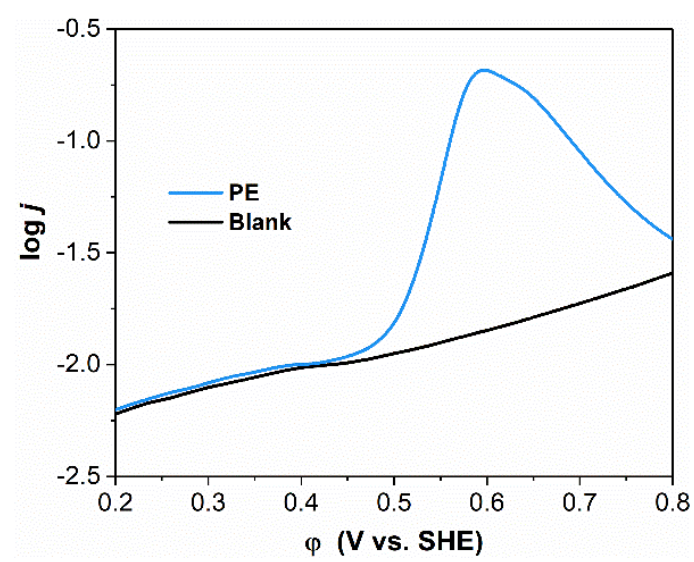

Figure S25. Tafel curves on the glassy carbon electrode in the electrolyte and phenol solutions. $\left(\mathrm{v}=1 \mathrm{mV} / \mathrm{s},[\mathrm{PE}]_{0}=0.1 \mathrm{mM},[\mathrm{PBS}]=20 \mathrm{mM}, \mathrm{T}=25^{\circ} \mathrm{C}\right.$ and $\left.\mathrm{pH}_{0} 7.3\right)$ 